\title{
The Study of Chinese Real Estate Enterprises Issuing Perpetual Bonds Financing: Advantage and Risk
}

\author{
Yao Jin \\ Management School, Jinan University, Guangzhou, China \\ Email:179728533@qq.com
}

Received 16 October 2014; revised 19 November 2014; accepted 27 November 2014

Copyright () 2014 by author and Scientific Research Publishing Inc.

This work is licensed under the Creative Commons Attribution International License (CC BY).

http://creativecommons.org/licenses/by/4.0/

(c) (i) Open Access

\begin{abstract}
In recent years, with the regulation of national policy, Chinese real estate market has been rapidly cooling, and real estate enterprises also have difficulties in financing. Perpetual bonds as a historic mezzanine financial instrument abroad was formally introduced into China in 2013 and its own characteristics can satisfy the current needs of the real estate enterprises. This paper analyzes the plight of the real estate market and real estate financing under the current environment, discusses the issue of perpetual debt financing, and analyzes the advantages and risks of issuing perpetual bonds in multiple aspects.
\end{abstract}

\section{Keywords}

Real Estate, Financing Difficulties, Perpetual Bonds, Financing Risks

\section{An Analysis of the Real Estate Business Woes}

\subsection{The Main Policy Influence of the Real Estate Business}

Since the government regulation started from 2005, the Central Bank issued a notice to contain the fast rising prices of real estate-the real estate bubble has begun to get people's attention. After the outbreak of the 2008's financial crisis, the state has invested a lot of bailout funds. But a large proportion of it finally flew to the real estate business, resulting in a new round of expansion of the real estate bubble, and causing more rigorous controlling measures on the real estate. The policies of 2011 and 2013 etc. began to restrict the real estate business.

\subsubsection{Policy of Purchase Restriction}

There are 48 cities which have issued the Limited Purchasing Order since 2011. The Limited Purchasing Order

How to cite this paper: Jin, Y. (2014) The Study of Chinese Real Estate Enterprises Issuing Perpetual Bonds Financing: Advantage and Risk. American Journal of Industrial and Business Management, 4, 709-715. 
mainly is used to restrict each family can only buy one commodity housing. The limited purchasing districts of real estate are expanded to the entire administrative areas of the city, and the limited purchasing types include all new and second-hand housing commodity housing. Because of the rigid requirements and elasticized differences of the government perform, the impacts on the regions are different; the trading volume of houses has declined in the first-tier cities which have strict policy implementation, while the volume has risen in the second and third-tier cities. Meanwhile, the real estate enterprises are also so conservative to the market forecasting that they are cautious about the price adjustment. Some cities have loosed the Limited Purchasing Order since 2014, but the current speed of real estate markets have slow down, and most companies are also facing the pressure of depreciation.

\subsubsection{Policy of Lending Restrictions}

The country mainly means to restrict the "Second Suite" trade, and raises its down-payment to 60\%, but the final impact on the intensity is limited. Because of the higher down-payment the proportion of lump-sum payment has increased, but it also prevented from many middle-investors.

\subsubsection{Policy of Affordable Housing}

The low proportion of affordable housing is an important factor leading of rising house prices. Only 7.2 percent of affordable housing in the 2008's commercial housing led to the demands of a large number low-income housing turned to the commodity house, so that the demands of commodity house continue to expand. In recent years, the construction of affordable housing has been strongly supported by the state, and 4.7 million units have been built and 6.3 million units have commenced in 2013. In the third quarter in 2014, China has built more than 6 million affordable houses ${ }^{1}$, so that the pressure of buying commodity house has been released, the demands of commodity house have reduced, and the sales of real estate markets have declined at a certain extent.

\subsubsection{Monetary Policy}

Under the financial crisis of 2008 and 2009, loose monetary policy led the national real estate market to be hot, and companies frequently paid an extraordinary high price to buy a land to build houses. But since 2010, the country began to tighten monetary policy; the Central Bank raised the interest rates again and again and reduced the scale of the real estate credit. At the same time, banks are so inclined to lend to large real estate companies that small and medium real estate companies are facing serious challenges in capital resource.

\subsubsection{Tax Policy}

"State's Eight Policies" in 2011 provide for individuals reselling house transactions less than 5 years, the tax shall be decided according to the full amount of sales. In 2013, it is clear that the personal income tax shall be strictly decided according to the $20 \%$ of taxable income. Meanwhile, the State accelerates the introduction and promotion of the real estate property tax. It makes the housing speculation have been curbed, and weaken the hot phenomenon of real estate.

From January to July in 2014, the sales area of the national commodity housing fell $7.6 \%$, and dropped about $20 \%$ in second and third-tier cities, 30\% percent in first-tier cities. And the national average prices of commercial residential housing also fell $1.2 \%$. In summary, we can see that the current real estate sales overall are in decline both in the sales area or sales prices, and it indicates that the pressure of eliminating the inventory is still enormous [1].

\section{Real Estate Financing Plight}

In 2013, the real estate development enterprises have available funds 12.2122 trillion yuan, increasing 26.5 percent over the previous year and rising 13.8 percent over 2012. It includes 1.9673 trillion yuan domestic loans, increasing 33.1\%; 53.4 billion yuan foreign investment, increasing 32.8\%; 4.7425 trillion yuan self-financing, increasing 21.3\%; 5.4491 trillion yuan other funding, increasing $28.9 \%$. In other funds, deposit and advance payment is 3.4499 trillion yuan, an increase of 29.9\%; individual mortgage loans are 1.4033 trillion yuan, an increase of $33.3 \%$. The study ${ }^{2}$ of these important data and historical literature indicate that Chinese real estate corporate are facing financing plight:

\footnotetext{
${ }^{1}$ National Bureau of Statistic of PRC's report. http://www.stats.gov.cn/

${ }^{2} 2013$ China Real Estate White Paper. Chinese Academy of Real Estate Data.
} 


\subsection{The Sources of Funding Still Overly Rely on Bank Loans, and the Difficulty in Financing Is Increasing under Tight Credit Policy}

At present, Chinese real estate development companies' financing approaches mainly rely on bank loans, issuance of stocks, bonds, trusts and other ways of financing just in small proportion. In recent years, Chinese real estate's financing approaches are huge affected by the macro-control; the difficulties in financing from bank loan are more and more. Data in 2013 showed that the self-financing accounted for $38.3 \%$ of all sources of funds; it means that under the situation of bank loans being difficult companies have to raise the self-financing ratio to relieve the pressure of cash flow, while some small companies are facing the pressure of funding chain breaking up [2].

\subsection{The Asset-Liability Ratio of the Real Estate Enterprises Is Generally Extremely High}

See from the recently reports by some real estate enterprises, the debt ratios of them are very high (see Table 1).

Excessive debt exacerbated the credit risk of real estate companies, increased the follow-up financing costs, and made it more difficult to financing.

\section{Chinese Real Estate Enterprises Issued Perpetual Bonds to Crack Financing Plight}

\subsection{The Concept of Perpetual Debt and Its Characteristics}

Perpetual debt is a kind of permanent capital instruments refers to no specified maturity (or especially long term), due to the provisions of the principal and interest, so called for a permanent subordinated bonds ${ }^{3}$. Such bonds were started to issue in foreign markets long time ago and began to receive attention in the Asian market in recent years. Thus, the domestic literature research for this bond is less, many of which are introduced only in the literature as a mezzanine financing capital instruments. The CICC, China Merchants Securities and other investment banks recent research report has been made some detail on perpetual bond, but it is also more elaborate its concept and release conditions [3]. Currently on the characteristics of perpetual bond summary are (see Table 2).

Therefore, perpetual bond is called "name Bonds, the real interest in”.

\subsection{Perpetual Bond's Application Advantages in the Real Estate Business}

October 2013 Wuhan Metro renewable starting up the first domestic bond market, which is a kind of perpetual bond. Followed in the same year in December, national electricity also issued perpetual bonds. Although both are perpetual bond issued, but the accounting treatment is different, the former included in liabilities, they are latter were recorded in equity, the difference is that, Wuhan Metro does not require payment of interest on the deferred, so interest must be paid on schedule, thus missing perpetual bond's “core” [4]. Although there are no real estate companies in the country issuing perpetual bond, but many of them are rely on Hong Kong bond market to have issued perpetual bonds overseas, such as Cheung Kong, Everglade, Agile Property and the like [5].

From the real estate business as the issuer's point of view:

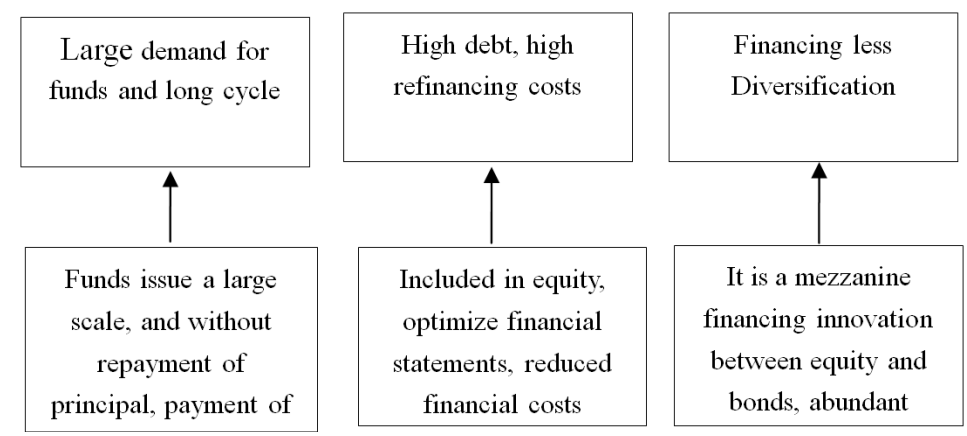

Extract from the CICC Research Report.

\footnotetext{
${ }^{3}$ The CICC 2014 Research Report.
} 
Table 1. Several large real estate companies’ asset-liability ratios.

\begin{tabular}{ccccc} 
& \multicolumn{4}{c}{ Company } \\
\cline { 2 - 5 } & Hengda Real Estate & R \& F Properties & Agile Properties & Shui on Land \\
\hline 2013 asset-liability ratio & $69.5 \%$ & $110.8 \%$ & $72.4 \%$ & $59 \%$ \\
\hline
\end{tabular}

Extract from companies financial statements.

Table 2. Compare perpetual debt and general corporate bonds.

\begin{tabular}{|c|c|c|}
\hline & Perpetual bonds & General bonds \\
\hline Interest & Rate is high, mostly between $6 \%-9 \%$ & $\begin{array}{l}\text { The longer term , the higher the interest rate. Current corporate } \\
\text { bond management regulations that corporate bond interest rate } \\
\text { shall not exceed } 40 \% \text { of the same period of household savings } \\
\text { deposit rates of banks }\end{array}$ \\
\hline Liquidation order & $\begin{array}{l}\text { Generally inferior to bonds and same of } \\
\text { subordinated bonds, but the priority of } \\
\text { repayment is higher than the common and } \\
\text { preferred stock }\end{array}$ & Higher than the subordinated bonds and stocks \\
\hline Principal payments & $\begin{array}{l}\text { The creditor does not have a defined point in } \\
\text { time to get the principal when the bond is not } \\
\text { redeemed }\end{array}$ & Got principal payment as the maturity date of bond \\
\hline Interest payment & $\begin{array}{l}\text { Settlement on a regular period (six months is } \\
\text { more common), but the interest payments can } \\
\text { be deferred }\end{array}$ & $\begin{array}{l}\text { Interest paid during one year or half of year generally; also } \\
\text { paying interest and principal together at the maturity date of } \\
\text { bond }\end{array}$ \\
\hline Interest rising & $\begin{array}{l}\text { Ascending after a redemption period, if the } \\
\text { company does not redeem the bonds, the } \\
\text { interest on floating accordingly, usually in } \\
\text { addition to calculate the interest on treasury } \\
\text { bills interest rate }\end{array}$ & $\begin{array}{l}\text { Fixed rate bonds does not change; floating rate bonds with a } \\
\text { floating market rate on a regular basis }\end{array}$ \\
\hline Guaranteed & Unsecured bonds & Generally require third-party guarantees \\
\hline Bond rating & Voluntary rating & $\begin{array}{l}\text { If bond is not issued by national bank financial institutions, } \\
\text { should be rated }\end{array}$ \\
\hline $\begin{array}{l}\text { Accounting } \\
\text { measurement }\end{array}$ & $\begin{array}{l}\text { Could be recorded in equity, are reported as } \\
\text { "permanent capital instruments" }\end{array}$ & $\begin{array}{l}\text { Recorded in liabilities, divided into "short-term liabilities", } \\
\text { "long-term liabilities" and other }\end{array}$ \\
\hline
\end{tabular}

Extract from the CICC Research Report.

First, the perpetual bonds only pay interest and don't need repay principal, the repayable order lower than the general bond, so that it is similar with the shares issued by a listed company and be regarded as equity rather than debt, but it does not affect the ownership structure. Real estate financing is generally large, long project cycle, which requires funding not only to meet their needs in terms of size, but also to reduce the pressure on the financing repayment period. The perpetual bond can get a lot of money at issue, at the same time, does not repay the principal, can satisfy the above-mentioned characteristics of real estate corporate finance.

Second, in March 2014 the Ministry of Finance issued the "distinction and the relevant accounting rules of financial liabilities with equity instruments" clearly in China's enterprises to meet the conditions of perpetual bonds may be reflected as equity instruments in the report ${ }^{4}$. The financial risk becomes large when the gearing ratio is high, so that the financing cost becomes high, perpetual bond under certain conditions may be included in equity items, which get a lot of money at the same time, increasing the asset class enterprise accounts, so that the perpetual bonds can reduce the asset-liability ratio while obtaining funds, which can reduce business costs in the refinancing.

Finally, real estate is currently financing a single, sustainable debt in the country belong to newborn product, it belongs to the range of mezzanine financing between debt and equity, such financing can help enrich the real estate business financing, optimized financing portfolio.

Clearly, perpetual bond has the advantage of its own, can be a good solution to the current difficulties of financing the real estate business.

${ }^{4}$ Ministry of Finance of PRC. http://www.mof.gov.cn/index.htm 


\section{The Risk Structure of Interest Rates of Perpetual Bond}

In recent years, the international financial crisis, such as the US subprime mortgage crisis, the European debt crisis, are associated with risks related to bonds, corporate bond defaults of the early 1990s occurred enterprise "triangular debts", plus some financial institutions to use debt fraud, forming a massive bad debts, resulting in serious losses of investors. Meanwhile, the US subprime mortgage crisis occurred in 2008, the culprit is excessive expansion of large-scale real estate loan defaults, caused a chain reaction. Visible, real estate credit risk position in the financial risk management and important.

Domestic and foreign bond financing for the study of risk has become mature and complete, and perpetual debt despite a long history, but it is innovation in the domestic release. Meanwhile, in our current financial environment and the development of real estate in a double turning point-Shanghai FTA establishment, began to develop a variety of financial derivatives, to carry out a broader financing platform to accelerate the establishment of financial innovation system; real estate in the government under the policy led to fluctuations in the environment are forced to increase the financing of new financing innovation. To be discussed in this context, is of great significance.

\subsection{The Interest Rate Risk}

As the bond market, risk-free interest rate changes will cause almost all bond prices changes. Risks from changes in interest rates led to a risk-free asset price changes is called the interest rate risk. For the risk-free rate, time is the only independent variable factor. Therefore, the description spot yields on a time-varying term structure of interest rates become the key of bond-pricing research.

Irving [6] raised the market expectations theory, he believes that the future market spot rate expectations and forward rates are equal, i.e. $E(r)=f$, then the relationship between the expression yield to maturity zero-coupon bond between the spot rate and future market for

$$
y_{n}=\sqrt[n]{\left(1+E\left(r_{1}\right)\right)\left(1+E\left(r_{2}\right)\right), \cdots,\left(1+E\left(r_{n}\right)\right)}-1 \quad t=2,3, \cdots, n
$$

Given the market is expected to be subject to strict theoretical assumptions, liquidity preference theory was amended this! The theory is that although a term bond yields can affect another term bond yields, but the alternative is between short and long term bonds have cost, and can not be replaced! Van [7] clear that long-term interest rates should not only be confined to predict future short-term interest rate information, but also the reaction to compensate for the risk of limited liquidity provided, which investors should take into account liquidity preference. Investors are risk averse assumption on the liquidity preference theory:

$$
y_{n}^{l}=\sqrt[n]{\left(1+y_{1}\right)\left(1+E\left(r_{2}\right)+l_{2}\right)\left(1+E\left(r_{3}\right)+l_{3}\right), \cdots,\left(1+E\left(r_{t}\right)+l_{t}\right)}-1
$$

Thus, the liquidity preference theory is that investors are risk averse, due to the longer duration bonds compared to shorter term bonds, less liquid, so investors are more willing to hold short term bonds in order to increase the attractiveness of long-term bonds, it must provide liquidity premium to holders of longer maturity bonds.

Perpetual bonds as derivative products between stocks and bonds have the dual characteristics, so the distribution of its risk will become complicated. Perpetual bonds is issued and traded in the bond market, therefore, the main risk facing the issue of cost changes caused by changes in market interest rates.

Combined domestic and international distribution characteristics can be seen in perpetual bonds, perpetual bonds issuance initial interest rate is often coupled with an initial interest margin and issuers' market's benchmark interest rate. Therefore, the issue should be considered in the initial level of the benchmark interest rate, while the changes in market interest rates will lead to changes in the initial spread, may making perpetual issuance costs rise. Meanwhile, perpetual bonds often set interest ascending terms, that's means after every period there will be a redemption period, redemption enterprises can freely choose whether you want to redeem the bond, if not, will have interest rates step-up, step-up calculation of the current rate is often based on a reference rate plus a certain nominal interest rates rise, which as the next redemption period, therefore, the interest rate of perpetual bonds issued in the current period to consider not only the interest rate, but also to focus on the future interest rate trends.

According to information, the level of china future interest rate of trends belong steadily, so the issue perpet- 
ual bonds in favor of the real estate business to lock the current rate. Coupled with the future of real estate control policies are no signs of relaxation, market expectations are a lack of confidence for the real estate market, and the future of real estate financing may further increase difficulty, therefore, at this time may be issued perpetual bonds optimize the asset structure, thereby reducing future financing costs.

\subsection{Default Risk}

Structural model default risk from BSM [8] model, in recent years has been in constant development and improvement! Black etc. and Merton other studies suggest that, in fact, owned by the company's assets for all creditors, the creditors of a call option give the holder the stock, while

$$
\text { Company Value }=(\text { assets-liabilities }, 0)
$$

Based on this, company's debt pricing from the perspective of options available. In this theoretical framework, the diffusion process to meet the company's value $V$ [9]

$$
\mathrm{d} V=(\alpha V-C) \mathrm{d} t+\sigma V \mathrm{~d} z
$$

where, $C$ is the unit of time the total cash flow, $\alpha$ is the expected value of the instantaneous rate of return on the underlying assets, the variance for the instantaneous rate of return on the underlying assets of the variance.

A huge amount of real estate perpetual debt issuance, while enterprises are faced with the next step-up bond rates had to redeem bonds premise, will face a huge amount of reimbursement which will have a significant risk of default. Therefore, investors will demand higher interest rates to compensate for the risk of default.

\subsection{Liquidity Risk}

Liquidity risk is the risk through a variety of modeling methods. Center literature by such methods is the bond pricing studies conducted Duffie [10] like. In the theoretical basis of the credit risk premium on the simple model, they made the process of bond pricing liquidity risk compensation method, which uses default and liquidity short-term interest rate correction process! Specifically, based on the risk-free interest rate and default intensity determined by the random process assumed liquidity premium obey stochastic process, and thus, bond prices can be obtained from the following expression:

$$
D_{0}(T)=E^{Q}\left[\exp \left(-\int_{0}^{T}\left(r_{t}+\lambda_{t}+\gamma_{t}\right) \mathrm{d} t\right)\right]
$$

Bond yields can also be expressed as:

$$
R_{t}=r_{t}-l_{t}+h_{t} \lambda_{t}
$$

Typically, the companies need to pay interest on the bonds on schedule, but the terms of perpetual bond often provides for the right of the issuer to choose has deferred payments, but the interest would be paid sooner or later. However, the payment deferred enterprises still face certain risks.

As can be seen, the real estate business is currently in the doldrums period profits, largely due to room control policies, such profit environment, the pressure increase in interest payments, repayment risk increased. If issued perpetual bonds, interest payments can be deferred to avoid the solvency risk, but in the long term, perpetual bond because it has no expiration date so that cause interest payments are the main source of revenue, interest income protection for investors becomes an important indicator of the extent of the value of bonds, therefore, if the business deferred interest payments too long, would cause perpetual bonds in the secondary market devaluation, so that investors face liquidity risk, which may increase investors' negative emotions enterprises, is not conducive to the subsequent issuance of debt sustainability.

\subsection{Financial Risk}

Although perpetual bonds recorded in equity capital instruments in the accounting treatment, thereby reducing the asset-liability ratio of enterprises, but in essence, perpetual bonds is more of a fight "edge ball" in the accounting measurement of financial instruments, the corresponding provisions are, in theory, this bond will become sustainable, but it does not mean in practice really no maturity. And while the companies' report will make landscaping, which virtually increase the enterprise risking greater risk operations by increasing debts 
scale.

Real estate enterprises in perpetual bonds issued behaved significantly. e.g. after Agile Property perpetual bonds issued in January 2013 succeeded in reducing the debt ratio, then released several batches of senior notes, as well as certain bank loans, the asset-liability ratio in 2013 of 72.4 percent, increased by $10 \%$ than the debt ratio in 2012 rate, but if treated perpetual bonds as liabilities, its debt ratio was $82.5 \%{ }^{5}$. The same example as well as R \& F Properties, which at the end of 13 asset-liability ratio is as high as $110 \%$, the removal of perpetual debt, compared with 114 percent impact.

This is confirmed from that perpetual bond can be resolved in real estate financing crisis, but also may bring excessive leverage [11]. Therefore, perpetual bond will indirectly lead to increased risk of real estate corporate finance.

\subsection{Risk Rating}

Perpetual bond's rating in the mainstream of international rating agencies often positioned as junk bonds, usually lower than the issued corporate rating, and its unsecured, the unsecured bond would be downgraded easily in the volatile market environment, which would lead to its devaluation caused investors were worried about company.

\section{Summary}

In summary, because of its own characteristics, perpetual bond can be a good fit of the financing needs of the real estate business, and also can be a good solution to break current major financing difficulties. From the internal environment, real estate companies need long-term stable financing and reduce financing costs. And from the external environment, there is no sign of relaxation of control measures on the real estate in the short term, so real estate financing needs to expand the channels. And as domestic investors demand for high risk bonds gradually expanded, the opportunities for real estate can be issued perpetual bonds which are becoming increasingly larger. So in the future, there will be more and more real estate companies considering issuing perpetual bond. But at the same time, sustainable domestic debt as a new thing also faces many challenges, the risks attendant also had to cope with caution, not only need to improve the regulatory system, market norms, but also with more mature companies, come together to develop into healthy and sustainable debt financial instruments.

\section{References}

[1] Liu, D.Z. (2013) Real Estate Corporate Finance: Business Matching, Financial Support and Policy-Speed. Zhongshan University Press, Beijing.

[2] Huang, Z.Z. and He, D.Y. (2009) China Real Estate Enterprise Financing Innovation, Mezzanine Financing. Journal of Shanghai Real Estate, 6, 20-25.

[3] Luo, Y., Chai, S.M. and Wei, Y.M. (2013) Overseas Perpetual Bonds Overview and Case Study. China Merchants Bank Bond Market Special Report, 4, 40-44.

[4] Zhang, J.J., Fan, J.J. and Yang, B. (2013) Sustainable Debt: The Overseas Experience and the Prospect of Domestic Study. Journal of Bonds, 11, 2-8.

[5] Hu, T. and Zhang, F.L. (2013) Perpetual Bond Crack for Real Estate Financing Problems: The Case of Agile. Real Estate Finance, 4, 344-351.

[6] Irving, F. (1930) The Theory of Interest. The Macmillan Company, New York.

[7] Van, H.J. (1965) Interest-Rate Rik and the Term Structure of Interest Rates. The Journal of Political Economy, 73, 344-351.

[8] Black, S. (1973) The Pricing of Options and Corporate Liabilities. Journal of Political Economy, 81, 637-654.

[9] Merton, R.C. (1974) Theory of Rational Option Pricing. Journal of Economics and Management Science, 4, $141-183$.

[10] Duffie, S. (2003) Credit Risk: Pricing Measurement, and Management. Princeton University Press, New York.

[11] Liu, L.J., Wang, J. and He, Y.Y. (2013) The Analysis of the Current Situation and Prospects for Tourism Real Estate in China. Proceedings of 2nd International Conference on Science and Social Research, 371-374.

\footnotetext{
${ }^{5}$ Extract from the 2013 finical report of Agile Property.
} 
Scientific Research Publishing (SCIRP) is one of the largest Open Access journal publishers. It is currently publishing more than 200 open access, online, peer-reviewed journals covering a wide range of academic disciplines. SCIRP serves the worldwide academic communities and contributes to the progress and application of science with its publication.

Other selected journals from SCIRP are listed as below. Submit your manuscript to us via either submit@scirp.org or Online Submission Portal.
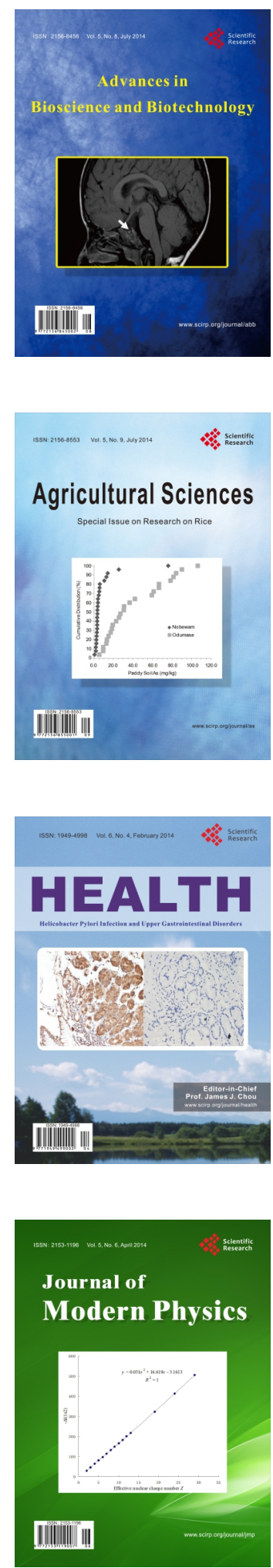
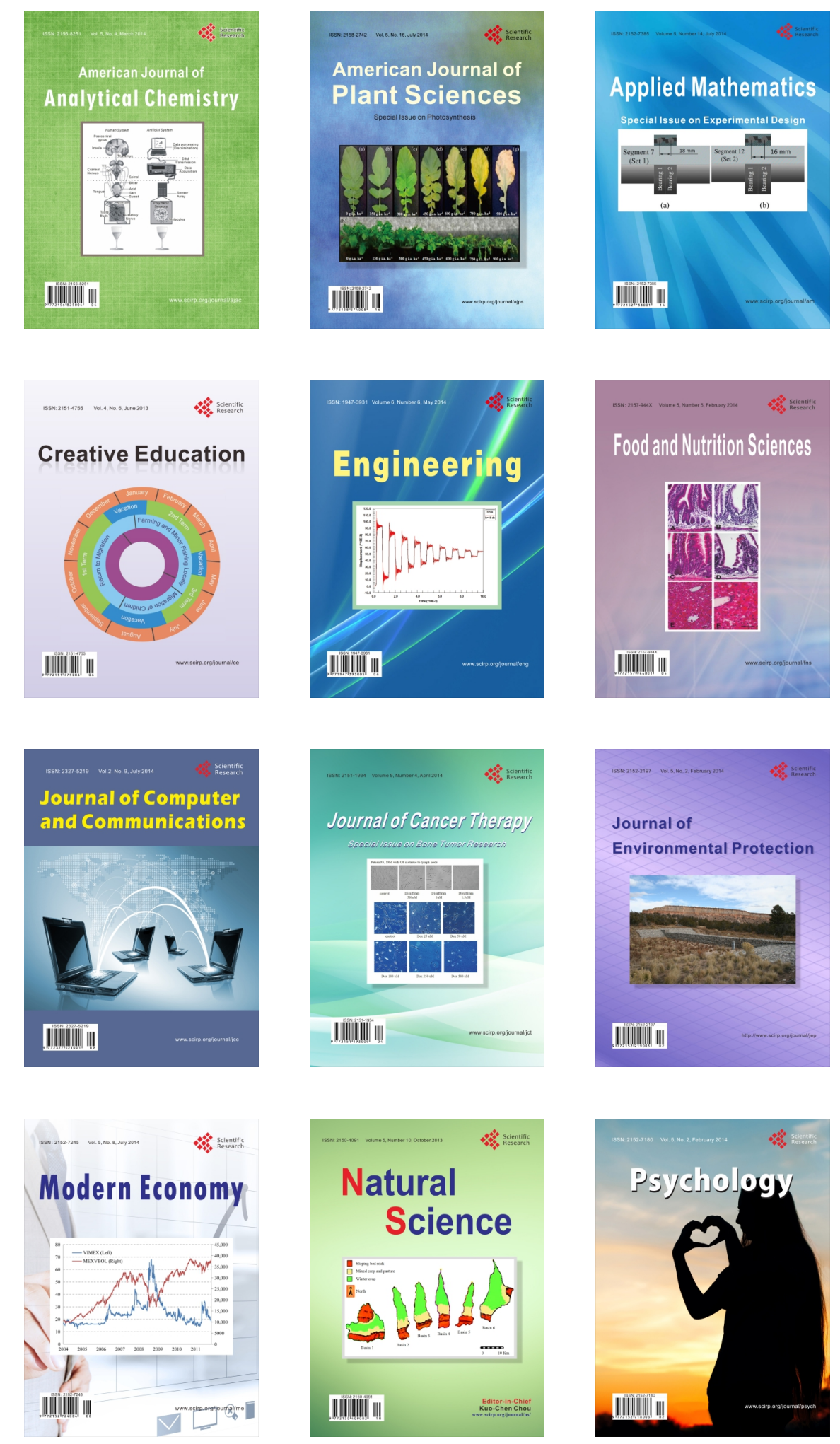